\title{
Development, Characteristics, and Effects of the New Chatham Harbor Inlet
}

by

\author{
Graham S. Giese, David G. Aubrey and James T. Liu \\ Woods Hole Oceanographic Institution \\ Woods Hole, Massachusetts 02543
}

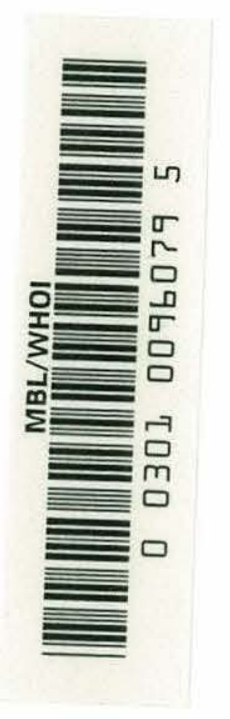

June 1989

\section{Technical Report}

Funding was provided by the Commonwealth of Massachusetts, Department of Environmental Management, Division of Waterways; the Town of Chatham; Woods Hole Sea Grant Program;

Massachusetts Office of Coastal Zone Management; U.S. Army Corps of Engineers

(New England Division and Coastal Engineering Research Center);

Town of Orleans; and Friends of Pleasant Bay.

Reproduction in whole or in part is permitted for any purpose of the

United States Government. This report should be cited as:

Woods Hole Oceanog. Inst. Tech. Rept., WHOI-89-19. CRC-89-4

Approved for publication; distribution unlimited.

Approved for Distribution:

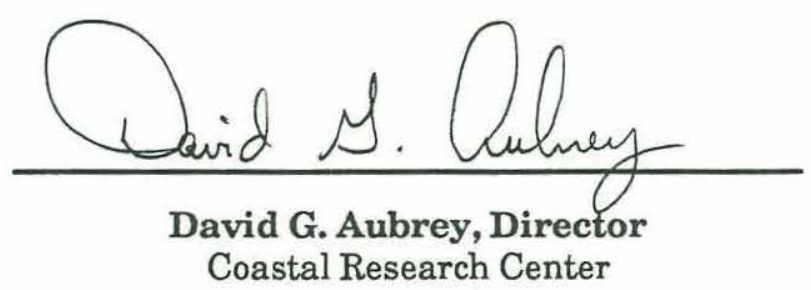




\section{TABLE OF CONTENTS}

PAGE

AbStract

ii

$\begin{array}{ll}\text { INTRODUCTION } & \mathbf{1}\end{array}$

BACKGROUND

$\begin{array}{ll}\text { METHODS } & 3\end{array}$

Morphological Observations 3

Aerial photographs 3

Beach profiles 5

Inlet position survey 5

Recession survey of the north end of the South Beach 5

Bathymetric surveys 5

Tidal Observations $\quad 6$

Tidal elevation $\quad 6$

Tidal currents $\quad 6$

$\begin{array}{lr}\text { RESULTS } & \mathbf{8}\end{array}$

New Inlet $\quad$. 8

Inner Shoreline Change $\quad 11$

Tidal Elevations $\quad 21$

$\begin{array}{lr}\text { Tidal Currents } & 23\end{array}$

DISCUSSION $\quad 29$

Tides $\quad 29$

Wave Action $\quad 29$

South Beach $\quad 30$

Inlet Channel and Shoals $\quad 30$

$\begin{array}{lr}\text { North Beach } & 30\end{array}$

$\begin{array}{lr}\text { PROPOSED FUTURE WORK } & \mathbf{3 0}\end{array}$

$\begin{array}{ll}\text { ACKNOWLEDGEMENTS } & 31\end{array}$

REFERENCES $\quad 32$ 


\begin{abstract}
A new tidal inlet into Chatham Harbor, Massachusetts, has developed from a breach in the barrier beach, Nauset Beach, that forms the outer shoreline of southeastern Cape Cod. Increased tidal range and wave energy resulting from the new inlet produced acute coastal erosion and channel shoaling within Chatham Harbor, with significant impacts on the fishing and boating industries, and on private and public property and interests. Study results are consistent with the hypothesis that the Nauset-Monomoy barrier beach system undergoes a long-term cycle of geomorphological change, and that a new cycle was initiated with the formation of this new inlet. Based on this new understanding, future changes in the system can be foreseen and provided to coastal resource managers.
\end{abstract}




\title{
DEVELOPMENT, CHARACTERISTICS, AND EFFECTS OF THE NEW CHATHAM HARBOR INLET
}

\author{
By G.S. Giese, D.G. Aubrey, AND James T. LiU \\ WOODS HOLE OCEANOGRAPHIC INSTITUTION \\ WOODS HOLE, MA 02543
}

\section{INTRODUCTION}

On January 2, 1987, during a severe northeasterly storm occurring together with a perigean spring tide, Nauset Beach was breached at a point almost directly east of Chatham Lighthouse (Figure 1), producing a complex of severe coastal management problems for the Town of Chatham. Increased tidal range and wave energy resulting from the new inlet produced acute coastal erosion and channel shoaling within Chatham Harbor, with significant impacts on the fishing and boating industries, and on private and public property and interests. Shoreline straightening processes resulted in rapid erosion, and in some cases accretion, along the inner shoreline in the vicinity of the new inlet. Some existing navigation channels shoaled or disappeared entirely, while new channels formed, most importantly the new inlet itself.

In response to these events, the Town of Chatham funded the Woods Hole Oceanographic Institution to carry out two studies that would provide input for resource management of the system. The first of these studies, "Impacts of Changes in Nauset Beach on Chatham Shoreline Forms and Tidal Levels", was designed to monitor shoreline changes and tidal levels along the western shore of Chatham Harbor. The study began May 1, 1987, and ended August 31, 1988. The second study, "Development, Characteristics and Effects of the New Chatham Harbor Inlet", was designed to measure and monitor the subaerial and submarine forms of the barrier beaches, inlets and channels associated with the Chatham Harbor system, and the tidal, wave and current characteristics of that system. This work was carried out between January 1 and June 30, 1988.

This report on the results of the two studies begins with a brief discussion of previous studies concerning shoreline changes in the Nauset Beach - Monomoy barrier system. Next, the study methods are described and the results presented, after which the results are discussed in terms of the geological processes controlling the system and the changes which the system may be expected to undergo in the years ahead.

\section{BACKGROUND}

Numerous studies carried out during the past century have contributed to the understanding of the evolution and patterns of change of Nauset Beach-Monomoy barrier system (e.g., Mitchell, 1874; Army Corps of Engineers, 1968; Oldale et al., 1971; Goldsmith, 1972; McClennen, 1979; 


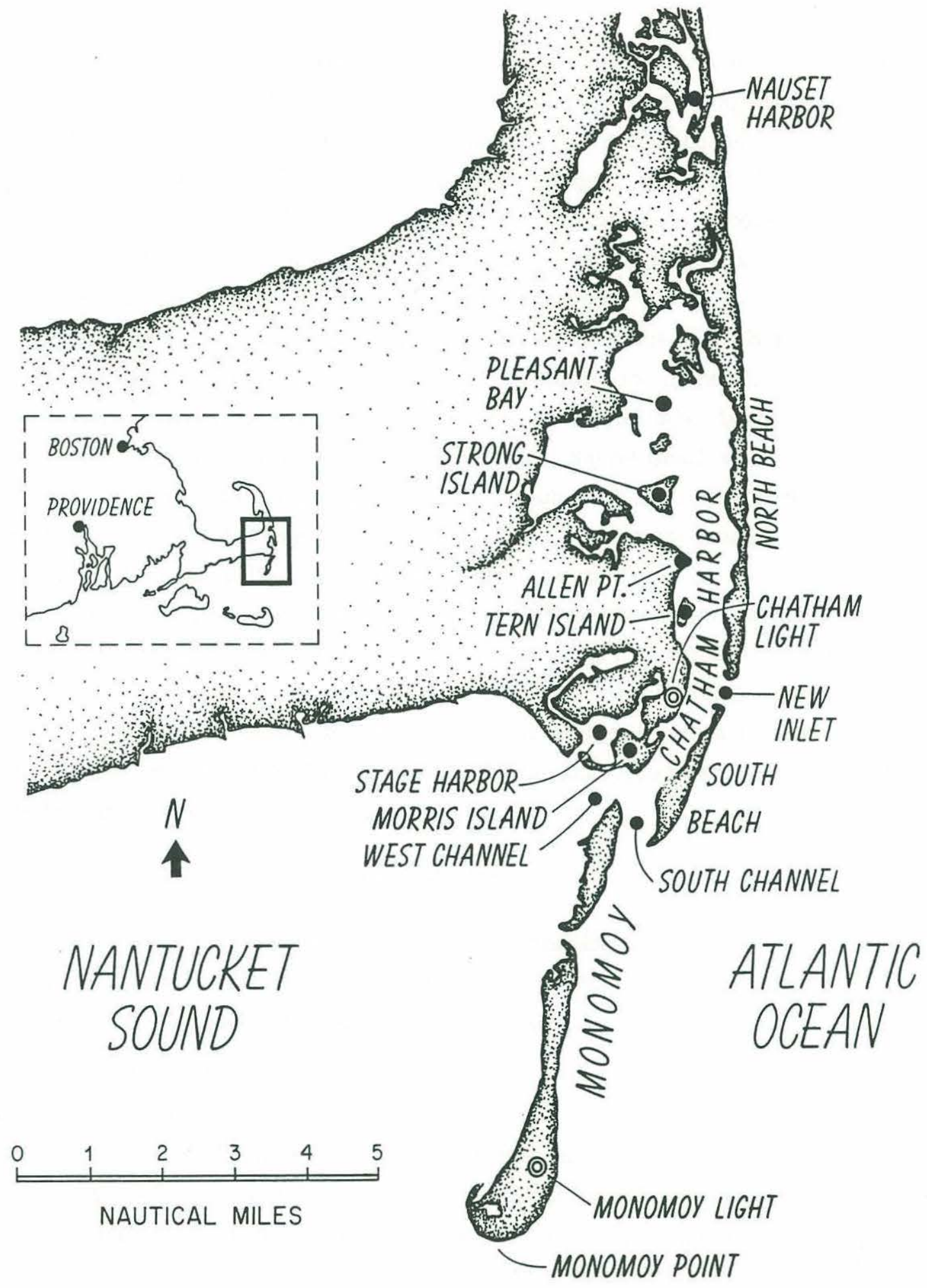

Figure 1. Location of study area, circa 1980. The tidal inlet east of Chatham Lighthouse, New Inlet, has been superimposed onto the earlier shoreline configuration, and designations used in this report for shoreline features have been added. 
TABLE 2.

Stevens Tide Gauge Records at Chatham Fish Pier

\begin{tabular}{lccc}
\hline Record Duration & Usability & Digitization & Harmonic Analysis \\
\hline April 1-15, 1987 & Interrupted & No & No \\
April 15-May 1, 1987 & Re-adjusted \& Interrupted & No & No \\
May 18-June 17, 1987 & Interrupted \& Malfunctioned & No & No \\
June 17-July 22, 1987 & Interrupted \& Malfunctioned & No & No \\
September 1-December 10, 1987 & good & (Sept. 1-Oct. 27) & Yes \\
December 10, 1987-March 7, 1988 & Interrupted, Malfunctioned & No & No \\
& scarce time check & & No \\
March 7-March 21, 1988 & Malfunctioned & No & No \\
April 5-May 2, 1988 & good & (April 5-May 2) & Yes \\
& & & \\
\hline
\end{tabular}

TABLE 3.

TDR Tide Records at Chatham Fish Pier

\begin{tabular}{lll}
\hline Record Duration & Usability & Harmonic Analysis \\
\hline $\begin{array}{lll}\text { May 17-June 15, 1987 } \\
\text { Manuary 20-February 17, 1988 }\end{array}$ & good & 29-day record \\
May 6-June 22, 1988 & good & 29-day record \\
& good & \\
\hline
\end{tabular}

TABLE 4.

TDR TIDE Records at MEeting House POND

Record Duration

Usability

Harmonic Analysis

March 28-May 1, 1987

April 4-May 1, 1988

May 6-June 22, 1988

$\begin{array}{ll}\text { good } & \text { 29-day record } \\ \text { good } & \text { 29-day record } \\ \text { good } & \text { 29-day record }\end{array}$


orthogonal tidal current components were measured using a Sea Data 635-9 electromagnetic current meter. This information will be used in future numerical modeling of the system's tidal hydrodynamics, and to help interpret tendencies for closure of inlets.

\section{RESULTS}

\section{New Inlet}

By April, 1988, fifteen months following the breaching of Nauset Beach, the opening had grown to a width of 5,800 feet, as measured from the south end of vegetation on North Beach to the north end of vegetation on South Beach. Since the opening measured 3,300 feet in April, 1987, more than half of the total widening occurred during the first three months. During the following three months, the size of the opening increased to 4,400 feet, thus reaching threequarters of the April, 1988, total within six months of the breaching. After that time the opening increased in size by amounts varying between 400 and 600 feet over each three-month period.

Measuring the width of the opening between the two vegetation lines is appropriate for determinations of the increasing size of disturbance to the pre-breach form of Nauset Beach. However, it is not a measure of the distance of open water separating North Beach from South Beach, because sand spits extend into the inlet and Chatham Harbor from both the north and south

TABLE 5.

\section{CURRENT METER DATA}

Location

South Channel

West Channel

Chatham New Inlet

Allen Point
Record Length

(Dates)
Measurements

$$
\text { P, T, U, V }
$$

7 April - 13 April, 1988

6 days $23 \mathrm{hrs} 50 \mathrm{~min}$

6 April-13 April, 1988

$$
\text { P, U, V }
$$

3 days $20 \mathrm{hrs}$ 20 April-4 May, 1988

$$
9 \text { days } 9 \mathrm{hrs} 50 \mathrm{~min}
$$
14 April-4 May, 1988

P: Water pressure, changes of which provide information on changes of water depth, primarily due to astronomical tides.

T: Water temperature.

U, V: Water flow. "V" denotes water velocity in the direction of magnetic north; "U" denotes velocity in the direction $90^{\circ}$ to the right of magnetic north. Velocities in any other direction, for example "down channel", can be derived from these. 
sides of the inlet (Figure 3). The open-water distance between the spits varies considerably because of the rapidity of changes in the spits themselves (discussed below). Obviously, variations in tidal level also change the spit-to-spit distance. At approximately low water on 5 May, 1988, the spit-to-spit distance was about 4,500 ft. as compared to a vegetation-to-vegetation distance of about $5,800 \mathrm{ft}$.

Patterns of change at the north end of South Beach differ considerably from those at the south end of North Beach. Soon after the initial breaching of Nauset Beach in January, 1987, a steep scarp was cut by wave action into the dunes at the north end of South Beach and a sand spit grew northwestward into the harbor from the dune scarp. Between January, 1987, and April, 1988, the dune scarp retreated southward about 3,500 feet, of which about 2,000 feet, or $57 \%$, was lost during the first three months (by April, 1987). After that time, the scarp retreated at a surprisingly constant rate, varying between 200 and 400 feet during each three-month period, with the slower rates occurring during summer months and the faster ones during winter.

The northwestward-trending sand spit at South Beach migrated southward together with the retreat of the dune scarp. In addition, it underwent a cyclical pattern of elongation followed by detachment from South Beach proper, followed by new spit formation and elongation. Spit detachment occurred in June, 1987, and in January, 1988, and thus appears to have a recurrence interval of about six months. The detached terminal lobes of the spits are reduced by wave and tidal action to intertidal shoals, and these shoals in turn migrate westward and southward. Thus the South Beach spits appear to play a significant role in the transport of sediment from South Beach into the lagoon separating South Beach from the inner shoreline of Chatham. These spits are also a key ingredient limiting tidal exchange between the southern, isolated portion of the Chatham system and the northern part of the system. The behavior of these "inlet-spits" at South Beach is the subject of a detailed study by investigators at the Department of Geology, SUNYOneonta (Weidman and Eberts, 1988).

As noted above, the pattern of change at North Beach was quite different from that at South Beach. Rather than scarping at the terminus, North Beach retreat involved overwashing of the southern terminal portion of the beach together with spit growth and spit detachment. By April 1988 , the total retreat of vegetation on North Beach amounted to 2,700 feet. Of that total, about $50 \%$ ( 1,400 feet) was lost during the first three months, and about $80 \%$ ( 2,200 feet) during the first six months (by July, 1987). After that time, the vegetation line retreated at rates varying between 100 and 300 feet during each three-month period. The sand spit at North Beach tended to grow southward and its southern terminus tended to hook into the harbor. Like the spit at South Beach, but less frequently, this spit also detached from its parent barrier beach and, when it did, the detached terminal lobe was overwashed by wave and tidal action and reduced to an intertidal shoal. The North Beach spit became detached in August, 1987, and once again in October, 1988. 


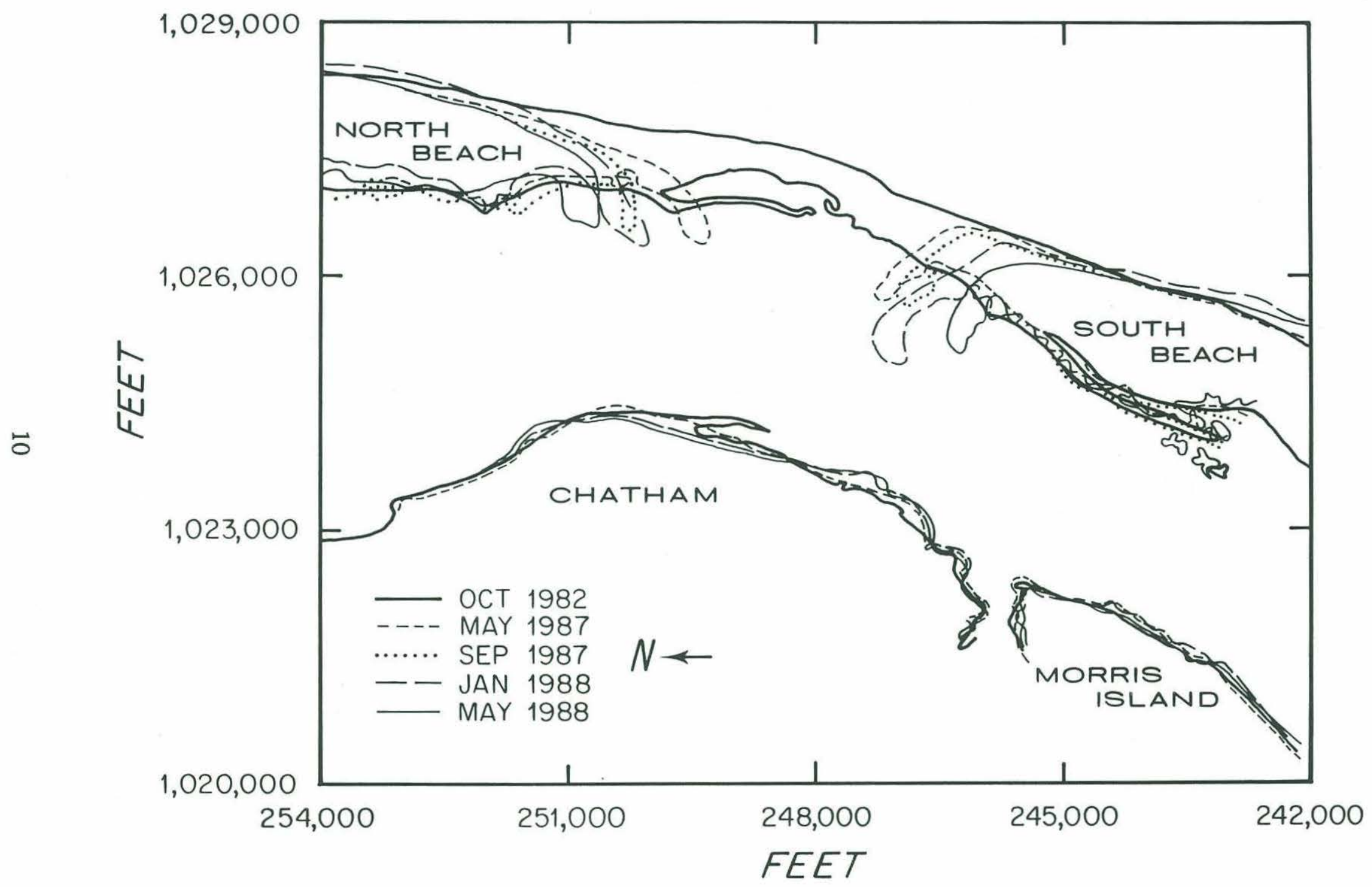

Figure 3. A composite of shoreline forms in the vicinity of New Inlet made by digitizing the shorelines on aerial photographs. The individual digitized forms for each time period are presented in Figure 4. The grid is based on the Massachusetts coordinate system, mainland zone. 
The sequential geomorphological changes of Chatham New Inlet, South Beach and the inner shore of the harbor since May 1987 are presented in Figures 4a through 4d. These maps are digitized aerial photos (uncorrected for distortion) which show the recession of the south end of North Beach and the north end of South Beach. The south end of South Beach, on the other hand, has accreted. Most changes on South Beach occurred at the two ends; the ocean and inner shorelines of South Beach were not significantly affected by the breach. Because of the recession on the north end and the accretion on the south end, South Beach appears to have migrated southward, maintaining a relatively constant geometry.

Figure 5 illustrates the subtidal shoals around New Inlet digitized from the May, 1988, aerial photographs. The ebb-tidal delta (ETD) is prominent as are accessory features. The main channel $(\mathrm{MCH})$, which bifurcates in the ebb-tidal delta, is flanked by channel margin bars (CHMB) on both sides. The channel margin bar on the south side separates the main channel from a secondary channel ( $\mathrm{SCH}$ ) which connects South Chatham Harbor (south of the breach) with the ocean. This channel is only active during high tide. The main channel, which formerly served South Chatham Harbor, turned about $90^{\circ}$ eastward into the new inlet, forming a wide bend. Shoals (S) formed on the south side of the bend, as a result of wave and tidal transport of material eroded from the north end of South Beach. These shoals block the exchange between the northern part and southern part of the harbor except through a small connecting channel $(\mathrm{CCH})$ at high tide. The position of the connecting channel(s) varies with changing wave action, as the shoals extend or shrink due to overwash.

The receding spit on North Beach left a broad and shallow platform (RPF) which is fed by littoral drift. Along the northern edge of the platform, there are several wave-formed swash bars (SB). The well-developed nearshore bar system (NB) probably serves as conduit for sediment transport along the ocean shore. North of the channel bend, the main channel is divided into a small branch and a major branch by a longitudinal bar (LB). Farther northward, the major branch splits into a flood-dominated channel ( $\mathrm{FCH})$ and an ebb-dominated channel (ECH), divided by a flood-tidal delta (FTD). Large transverse bars are superimposed on the flood ramp of the floodtidal delta. The flood-tidal delta also has a well-developed ebb shield. These morphological features change continuously through time as wave and tide conditions vary. Management of this resource must recognize the constant change and fluctuations that take place around the inlet, as sand bodies and new minor channels form and migrate. These higher frequency fluctuations are superimposed on lower frequency changes, such as southward migration of the inlet. The two types of change must be distinguished, to avoid overreaction by management personnel.

\section{Inner Shoreline Change}

After the breaching of Nauset Beach in January, 1987, dramatic changes occurred along the inner shoreline of Chatham Harbor from Morris Island northward to Claflin Landing. The initial 

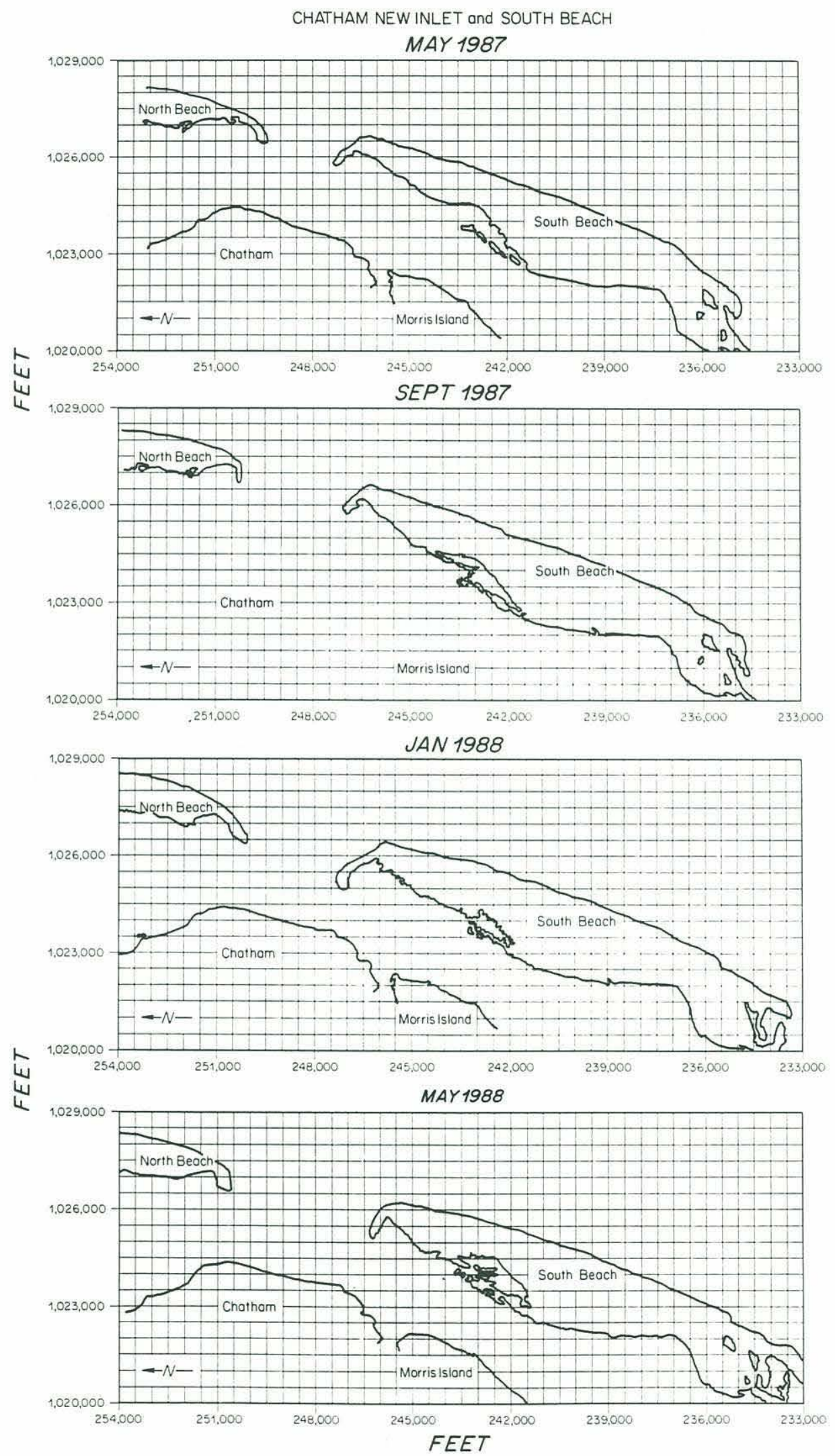

Figure 4. Shoreline forms at Chatham New Inlet and South Beach digitized from vertical aerial photographs made at 4-month intervals following the initial breaching of Nauset Beach. 


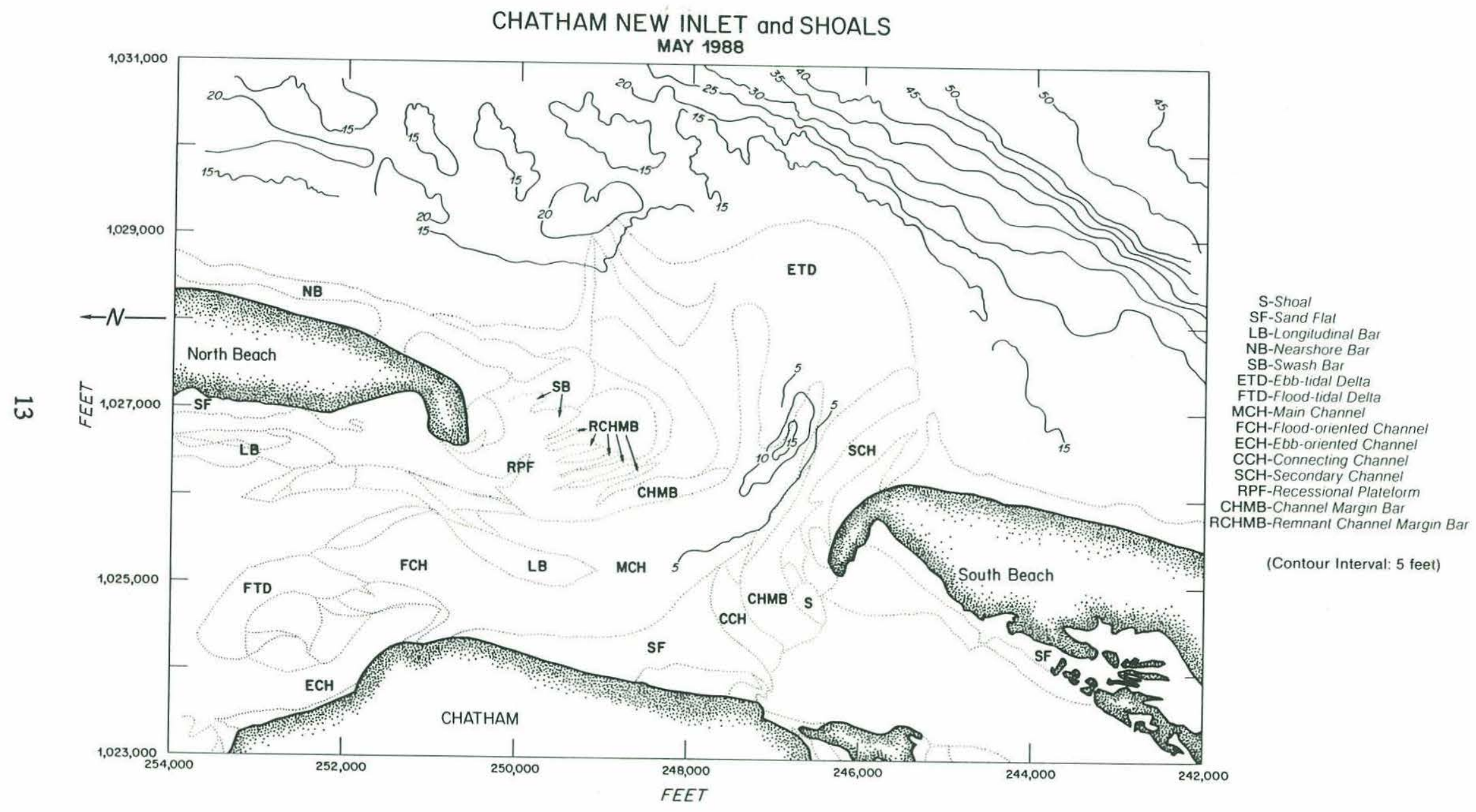

Figure 5. Subtidal and intertidal shoals in the vicinity of New Inlet digitized from vertical aerial photographs taken in May, 1988, shown together with bathymetric contours, relative to mean low water, of the channel throat and ebb-tide delta outer margin from the April, 1988, survey. 
adjustment of the shore to the increased wave energy and tidal range took the form of shoreline straightening, during which small scale promontories were eroded and embayments were filled, so that by May, 1987, a relatively smooth and linear shoreline had formed. Those initial changes are evident on the plotted results of shoreline change between March and April - May, 1987, for Morris Island (Figure 6), Little Beach (Figure 7), Chatham Lighthouse (Figure 8), Holway Street (Figure 9), and Claflin Landing (Figure 10). Only at Cowyard Landing (Figure 11), well protected by Tern Island from waves entering through New Inlet, was there no significant initial change.

Following the initial adjustments, however, there was little change at the Morris Island and Claflin Landing lines other than expected seasonal oscillations. In contrast, major shoreline changes were evident at Little Beach, Chatham Lighthouse and Holway Street, indicating rapid erosion north of Chatham Lighthouse and accretion to the south, and resulting in a significant counter-clockwise reorientation of this shoreline reach. The zone of greatest erosion during the study period extended north from Water Street to Mattaquason Point, a distance of approximately 2,000 feet. That erosion produced great damage to the ten shorefront properties between Andrew Hardings Lane and Holway Street, resulting in the loss of one summer cottage and the forced removal of others.

Between March, 1987, and February, 1988, the high tide line at Holway Street retreated 75 feet (Figure 9). In an attempt to reduce the shoreline retreat, a line of boulders was placed on this stretch of beach beginning in December, 1987. This action resulted in accelerated erosion at Andrew Hardings Lane, just south of the line of boulders, where an approximately 150-foot shoreline retreat occurred between May, 1987, and May, 1988 (based on analysis of aerial photography).

The high rates of erosion in this region resulted from the vigorous wave action reaching the shore at extreme high tides; this vigorous wave action, in turn, resulted from a number of factors related to New Inlet. Most important, of course, is the exposure to higher tides and ocean waves provided by the inlet. In addition, however, the curving form of the channel from the inlet into Chatham Harbor played a significant role, because in sweeping by the inner shoreline between Andrew Hardings Lane and Mattaquason Point, it brought deep water near the shore, allowing waves to break directly on the eroded scarp, and prohibiting deposition of sediment offshore. This deeper, high velocity water also scoured the inner shoreline, as on the outside of a river meander (Aubrey and Speer, 1984).

Waves entering New Inlet and crossing Chatham Harbor at higher tide levels were refracted by the pattern of shoals so as to be directed southward of shore-normal when they reached the shore. As a result, they produced a significant southward transport of sediment which was deposited along the shoreline southward from Chatham Lighthouse to Little Beach. The terminus of these deposits took a lobate or tongue-like form. The advance of such a depositional lobe across 


\section{BEACH PROFILES AT MORRIS ISLAND}

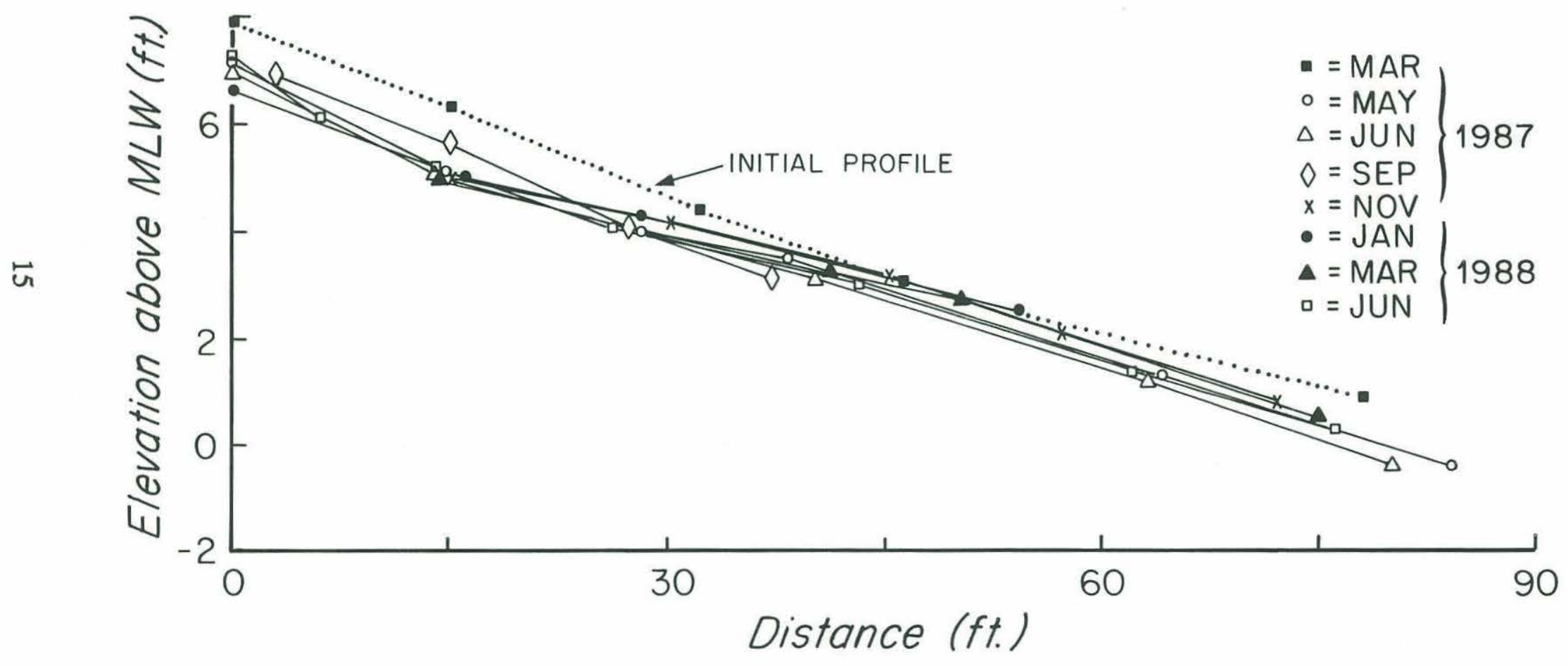

Figure 6. Beach profile at Morris Island between March, 1987, and June, 1988. 


\section{BEACH PROFILES AT LITTLE BEACH}

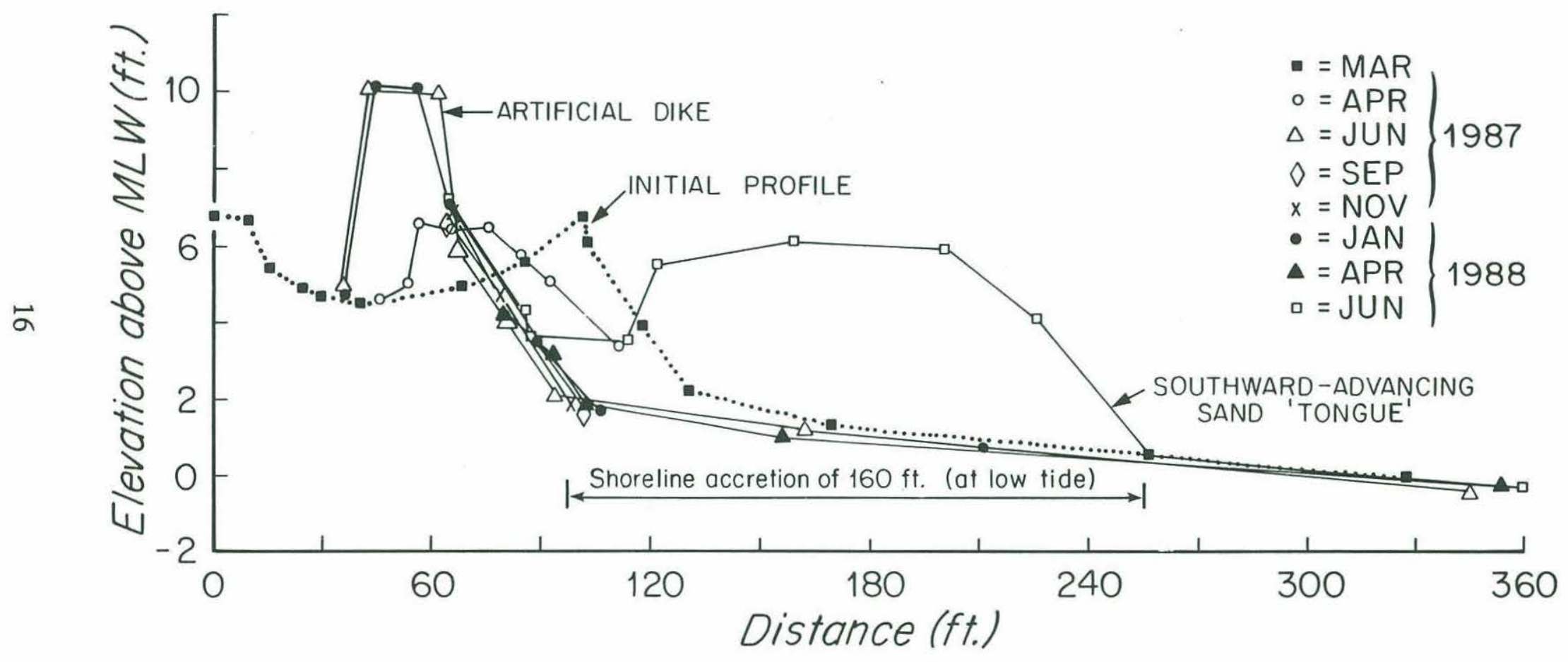

Figure 7. Beach profile at Little Beach between March, 1987, and June, 1988. 


\section{BEACH PROFILES AT CHATHAM LIGHTHOUSE}

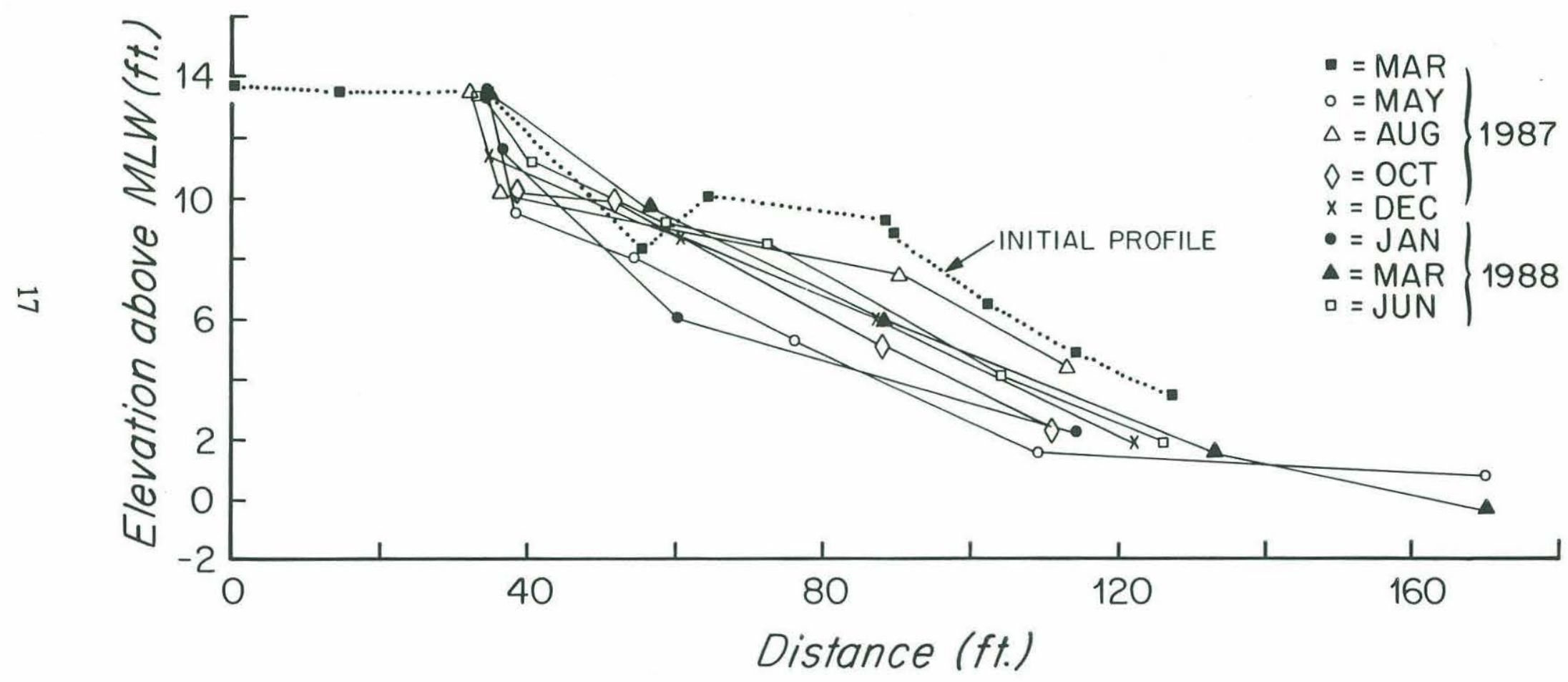

Figure 8. Beach profile at Chatham Lighthouse between March, 1987, and June, 1988. 


\section{BEACH PROFILES AT HOLWAY STREET}

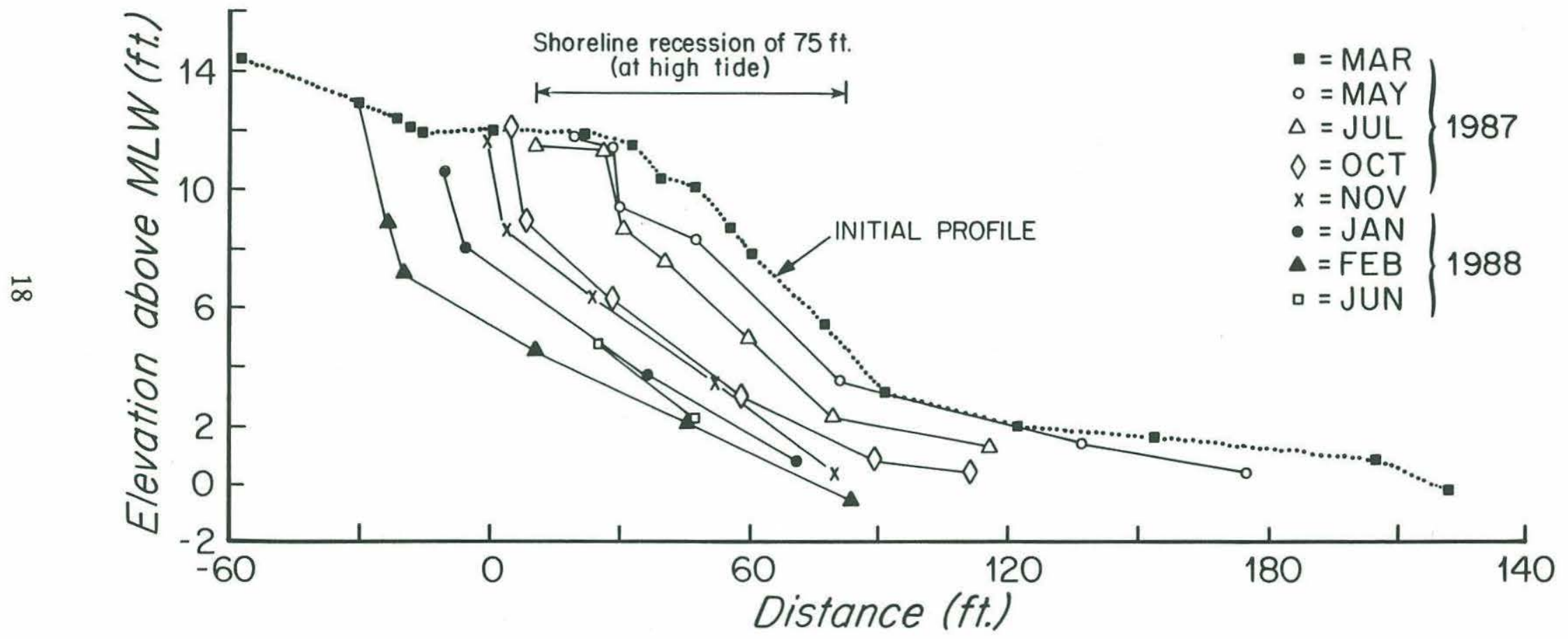

Figure 9. Beach profile at Holway Street between March, 1987, and February, 1988, with two data points for June, 1988. 


\section{BEACH PROFILES AT CLAFLIN LANDING}

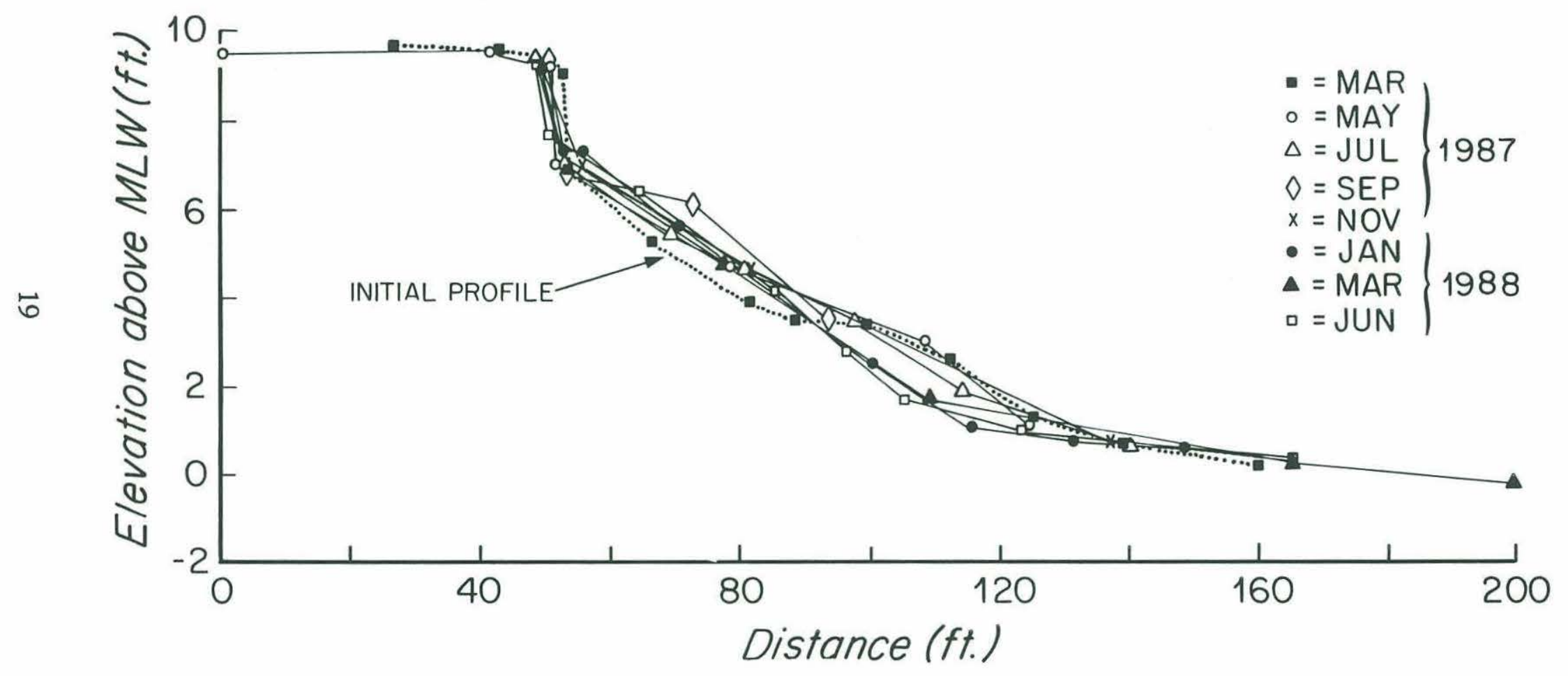

Figure 10. Beach profile at Claflin Landing between March, 1987, and June, 1988. 


\section{BEACH PROFILES AT COWYARD LANDING}

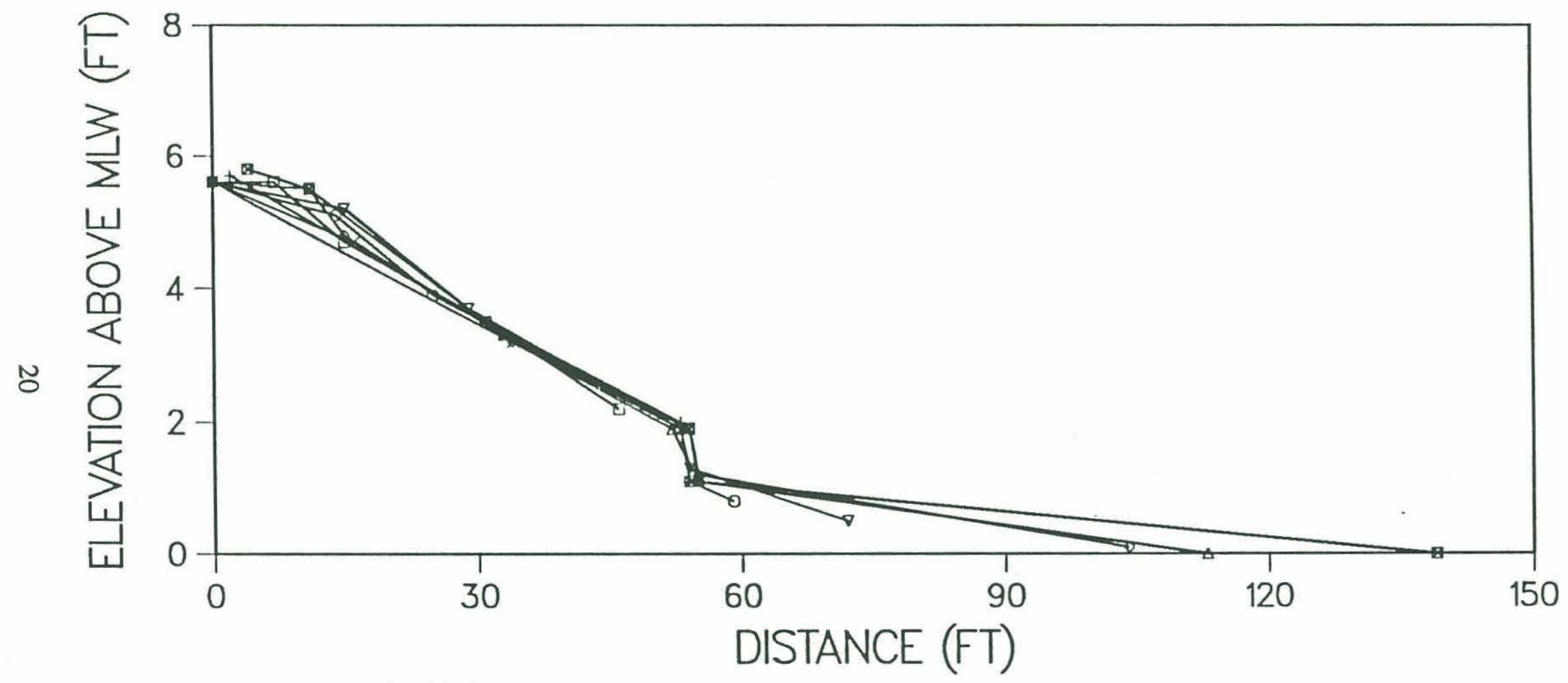
- = MAR '87
$\circ=$ MAY '87
$\triangle=$ JUN' 87
$+=$ SEP '87
$x=$ DEC ' 87
- = FEB '88
$\checkmark=$ APR ' 88
" = JUN '88 
the survey line at Little Beach between April and June, 1988, can be seen in Figure 7. Small scale erosion occurred between the lobes, and the artificial dike shown in Figure 7 was constructed in part to prevent the erosion that occurred at that site prior to the arrival of the depositional lobe. Significant southward sediment transport occurred even southward of lobes as indicated by the frequent filling by sand of the small boat launching basin at the marina located at the southern part of Little Beach near the Morris Island dike (Outermost Harbor).

An interesting feature of the sediment transport system in this region was the dynamic stability of the beach at Chatham Lighthouse. After an initial retreat of approximately 50 feet between March and May, 1987, this beach maintained a relatively constant form, with the expected seasonal variations of cutting in winter and filling in summer, despite its exposure to energetic southward-directed wave energy. Such stability is possible only because sediment was arriving at this point from the north as rapidly as it was being removed to the south. Should shoreline erosion north of Chatham Lighthouse be controlled - by seawall construction, for instance - without addition of a comparable rate of sediment supply, rapid erosion would occur.

\section{Tidal Elevations}

Figure 12 shows the 29-day record of tidal heights at each of the five locations during the April-May, 1988, synoptic deployments. These curves show that the tides around Chatham Harbor are strongly dominated by the semidiurnal lunar tide $\mathrm{M}_{2}$ (period of $12.42 \mathrm{hr}$, see Table 6) which contributes between $79 \%$ to $89 \%$ of the mean tidal heights at the five sampling locations. In addition to $\mathrm{M}_{2}$, each record also shows a slight diurnal inequality as indicated by the lower high tide and higher low tide during each day. The record at the ebb-tidal delta represents the shallow-

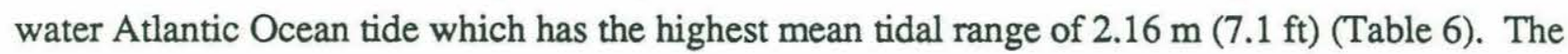
tide at South Channel is similar to the Atlantic Ocean tide and has a mean tidal range of $1.98 \mathrm{~m}$ (6.5 $\mathrm{ft}$ ). The Atlantic Ocean tide at both the ebb-tidal delta and South Channel shows a conspicuous fortnightly spring-neap cycle. As the ocean tide enters into the harbor, it interacts with the estuary floor and tidal channels due to the shallow depths. This interaction results in the damping of the tidal energy as demonstrated by the decreasing mean tidal range to $1.33 \mathrm{~m}(4.4 \mathrm{ft})$ at Fish Pier and $1.24 \mathrm{~m}$ (4.1 ft) at Meeting House Pond. Accompanying the damping is also the distortion of the tide as shown by the faster rise of the water surface during flood, and slower fall during ebb (flood dominated) in the tide records from Fish Pier and Meeting House Pond (Figure 12). This distortion is mainly due to the growth of an overtide $\mathrm{M}_{4}$, which has one-half the period of $\mathrm{M}_{2}$ (see Table 6 and Aubrey and Speer, 1985, for explanation). The degree of distortion is conventionally expressed by the ratio of the amplitude of $\mathrm{M}_{4}$ to that of $\mathrm{M}_{2}$ and the relative phase between the two as determined by the harmonic analysis. Table 6 is a short summary of the harmonic analysis results, which shows the increase of $\mathrm{M}_{4} / \mathrm{M}_{2}$ from the ebb tide delta to Meeting House Pond. This indicates that as the tide travels northward toward Pleasant Bay, it becomes increasingly distorted. 


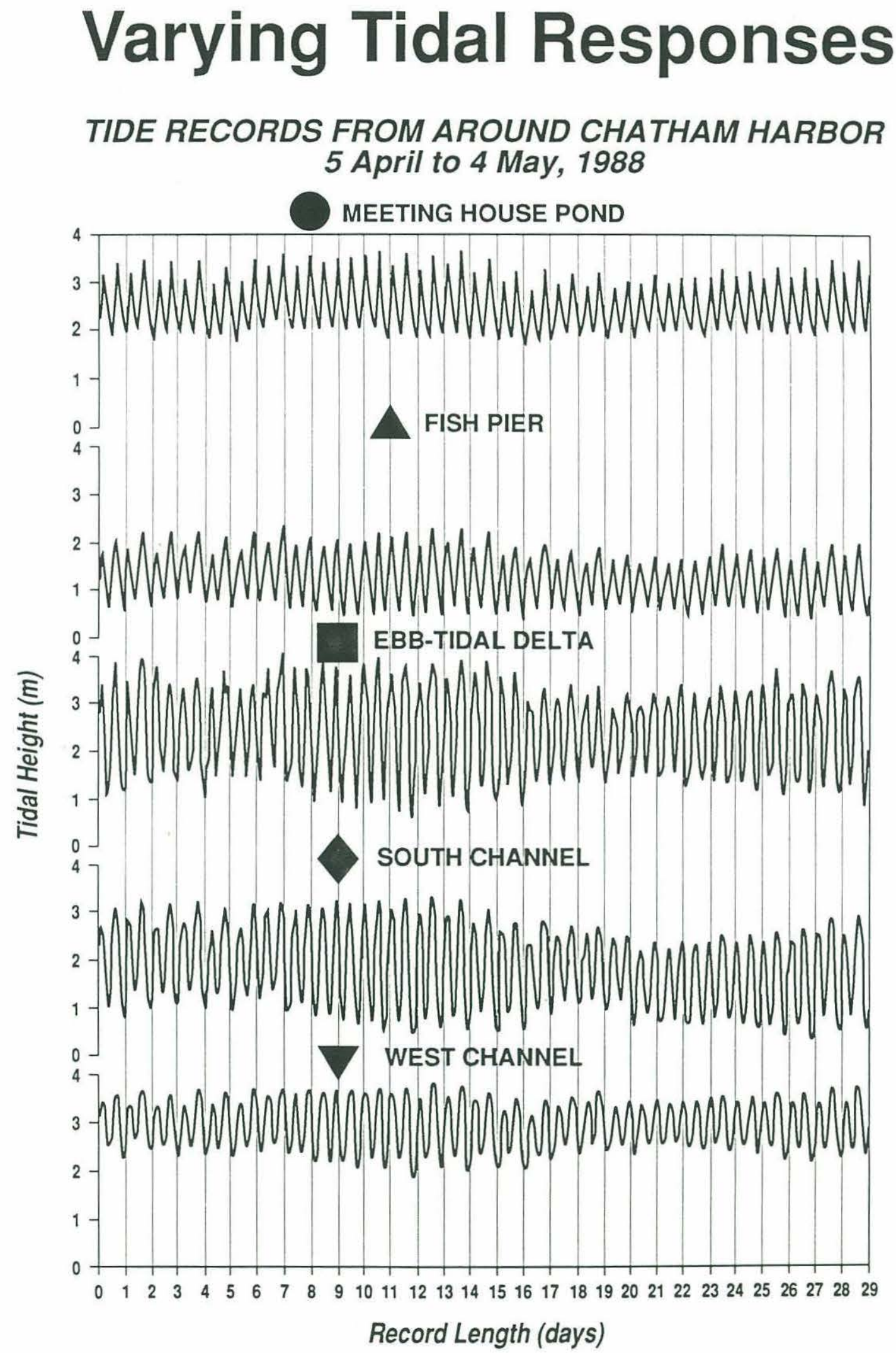

Figure 12. Comparison of tide records between 5 April and 4 May, 1988, from five locations in the study area. 
The tides in West Channel have the smallest mean tidal range due to the influence of Nantucket Sound tides which have a lower range than those in the Atlantic Ocean.

TABLE 6

SPATIAL TIDAL ChaRACTERISTICS

\begin{tabular}{lccc}
\hline \multicolumn{1}{c}{ Location } & $\begin{array}{c}\text { Mean Square Root } \\
\text { Tidal Range (m) }\end{array}$ & $\mathrm{M}_{4 / \mathrm{M}_{2}}$ & $\begin{array}{c}\text { M4-Melative Phase } \\
\left(^{\circ}\right)\end{array}$ \\
\hline Meeting House Pond & 1.24 & 0.219 & 54.8 \\
Fish Pier & 1.33 & 0.052 & 75.3 \\
Ebb-Tide Delta & 2.16 & 0.025 & -75.5 \\
South Channel & 1.98 & 0.031 & 94.3 \\
West Channel & 1.18 & 0.086 & -108.09 \\
\hline
\end{tabular}

NOTE

The accepted methodology for describing astronomical tides is to decompose the complex record obtained from a particular location into a series of simple sinusoidal curves that, when added together, will approximate closely the original record. At Chatham, the major such sinusoidal curve (or "harmonic constituent" as these curves are usually called) has a period of 12.42 hours. It is called the semidiurnal lunar tide and is designated " $\mathrm{M}_{2}$ ". The "pure" $\mathrm{M}_{2}$ tide has a regular rise and fall of equal time length, but in fact the Chatham tides are distorted to a degree that varies from place-to-place. The characteristics of this distortion are determined by the relative phase and amplitude of another harmonic constituent, designated "M4", which has a period of 6.21 hours, just half that of the $\mathrm{M}_{2}$ tide. A more detailed discussion of the $\mathrm{M}_{2} / \mathrm{M}_{4}$ interaction can be found in a recent study by Aubrey and Speer (1985).

Temporally, the changes of the tidal characteristics at Fish Pier are summarized in Table 7. There is no apparent trend to the variations in tidal range over time. All of the five values are within $4 \%$ of their mean value of $1.38 \mathrm{~m}$ (4.5 ft). However, there is an almost two-fold change of $\mathrm{M}_{4} / \mathrm{M}_{2}$, which indicates increasing tidal distortion in time. At Meeting House Pond, located at the northern extremity of Pleasant Bay (Table 8), the mean tidal range also appears steady, each of the three values being within $4 \%$ of their mean value of $1.19 \mathrm{~m}(3.9 \mathrm{ft})$. As at Fish Pier the $\mathrm{M}_{4} / \mathrm{M}_{2}$ ratio displays an increasing trend indicating the further distortion of the ocean tide.

\section{Tidal Currents}

The simultaneous measurements of water surface elevation and tidal current speed near the mouth of New Inlet are plotted in Figure 13. Currents flowing through New Inlet are swift. Maximum flood currents can exceed $100 \mathrm{~cm} / \mathrm{sec}(1.9 \mathrm{kt})$, and maximum ebb currents can exceed $140 \mathrm{~cm} / \mathrm{sec}(2.7 \mathrm{kt})$. On the average, during the sampling period, the maximum flood speed 


\section{Chatham New Inlet}

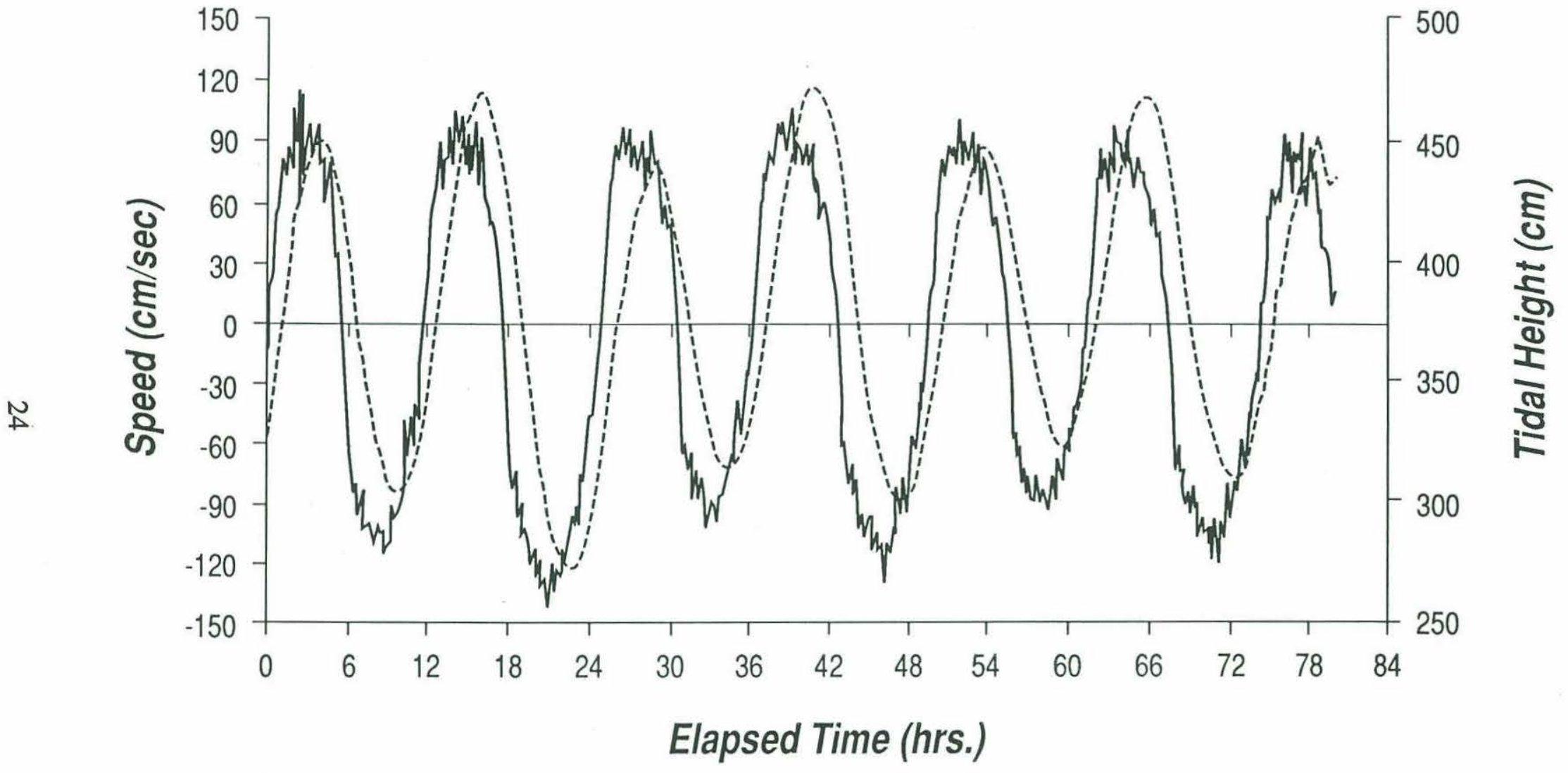

Current Speed

Tidal Height

Figure 13. Tidal currents and tidal elevations at New Inlet for a three-day period in April, 1988. Flood currents are positive, ebb negative. 
precedes the high water by approximately two hours during the flood, and the maximum ebb speed precedes the low water by about 1 hour and $45 \mathrm{~min}$. This indicates that the tide through the new inlet displays mixed characteristics of both a progressive wave and a standing wave. Farther north at Allen Point, the strength of the tidal currents has been reduced slightly by propagating through the channel (Figure 14). At this location, the tidal characteristics have become more standing than at the harbor entrance, such that maximum flood current precedes high water by 2 hours and 30 minutes, and maximum ebb current precedes the low water by 3 hours 45 minutes.

At South Channel the tide displays similar characteristics of a mixed progressive and standing wave (Figure 15). Maximum flood current precedes high water by 1 hour 30 minutes, and maximum ebb current precedes low water by 2 hours 19 minutes. The tide propagates through West Channel mainly as a progressive wave as indicated by the near coincidence of maximum westward (positive) current with high water (Figure 16), while maximum eastward lags low tide

TABLE 7

Temporal Tidal Characteristics at Fish Pier

\begin{tabular}{lccc}
\hline \multicolumn{1}{c}{ Time } & $\begin{array}{c}\text { Mean Square Root } \\
\text { Tidal Range }(\mathrm{m})\end{array}$ & $\mathrm{M}_{4} / \mathrm{M}_{2}$ & $\begin{array}{c}\mathrm{M}_{4}-\mathrm{M}_{2} \text { Relative Phase } \\
\left({ }^{\circ}\right)\end{array}$ \\
\hline May 1987 & 1.39 & 0.039 & 99.6 \\
September 1987 & 1.37 & 0.051 & 110.3 \\
January 1988 & 1.41 & 0.052 & 91.7 \\
April 1988 & 1.33 & 0.052 & 75.3 \\
May 1988 & 1.40 & 0.070 & 85.6 \\
\hline
\end{tabular}

TABLE 8

Temporal Tidal Characteristics at Meeting house Pond

\begin{tabular}{lccc}
\hline \multicolumn{1}{c}{ Time } & $\begin{array}{c}\text { Mean Square Root } \\
\text { Tidal Range (m) }\end{array}$ & $\mathrm{M}_{4 / \mathrm{M}_{2}}$ & $\begin{array}{c}\mathrm{M}_{4}-\mathrm{M}_{2} \text { Relative Phase } \\
\left({ }^{\circ}\right)\end{array}$ \\
\hline March 1987 & 1.19 & 0.206 & 57.8 \\
April 1988 & 1.24 & 0.219 & 57.5 \\
May 1988 & 1.15 & 0.246 & 58.3 \\
\hline
\end{tabular}




\section{Allen Point}

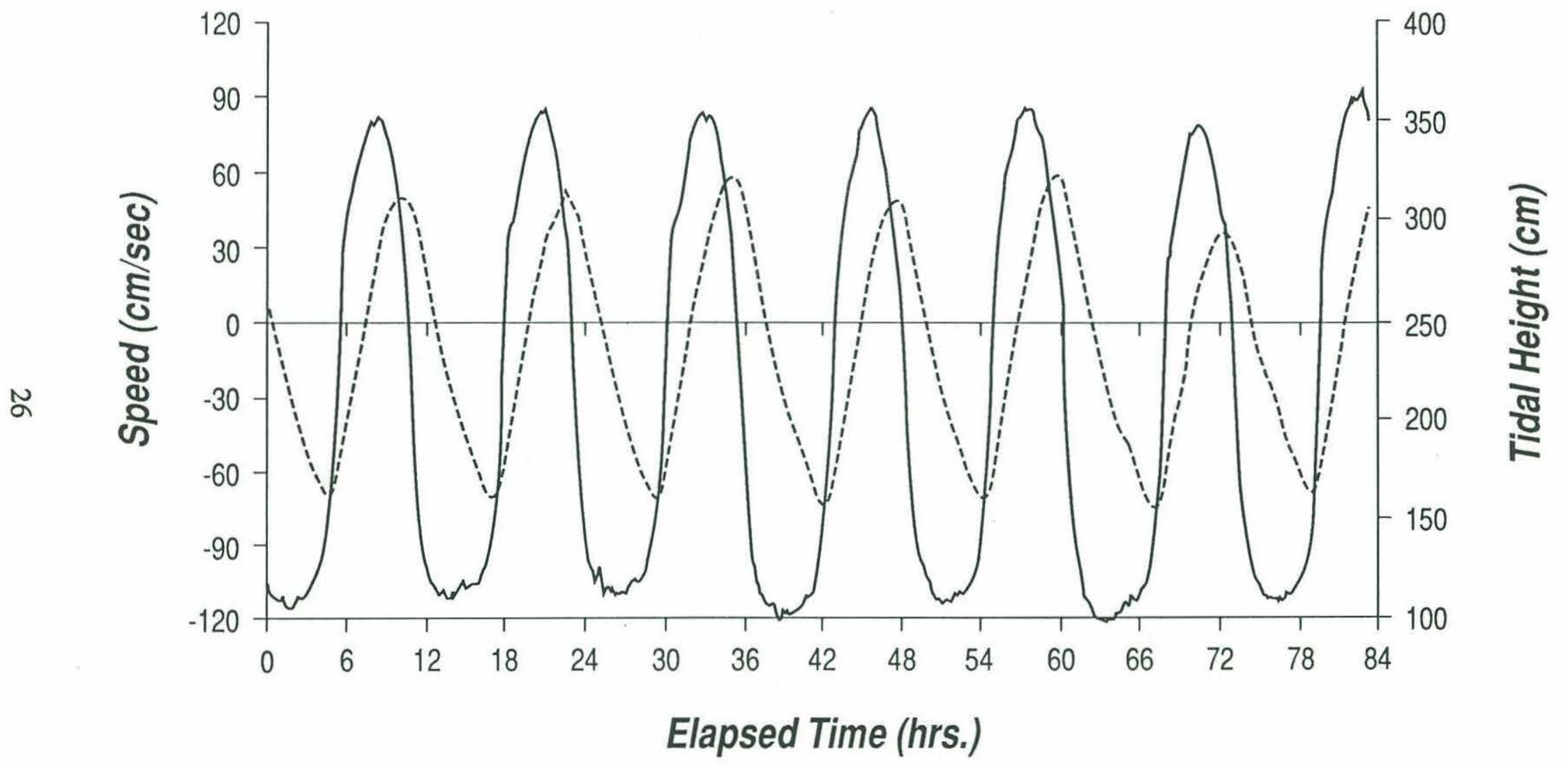

Current Speed

Tidal Height

Figure 14. Tidal currents and tidal elevations at Allen Point for a three-and-a-half-day period in April, 1988. Flood currents are positive, ebb negative. 


\section{South Channel}

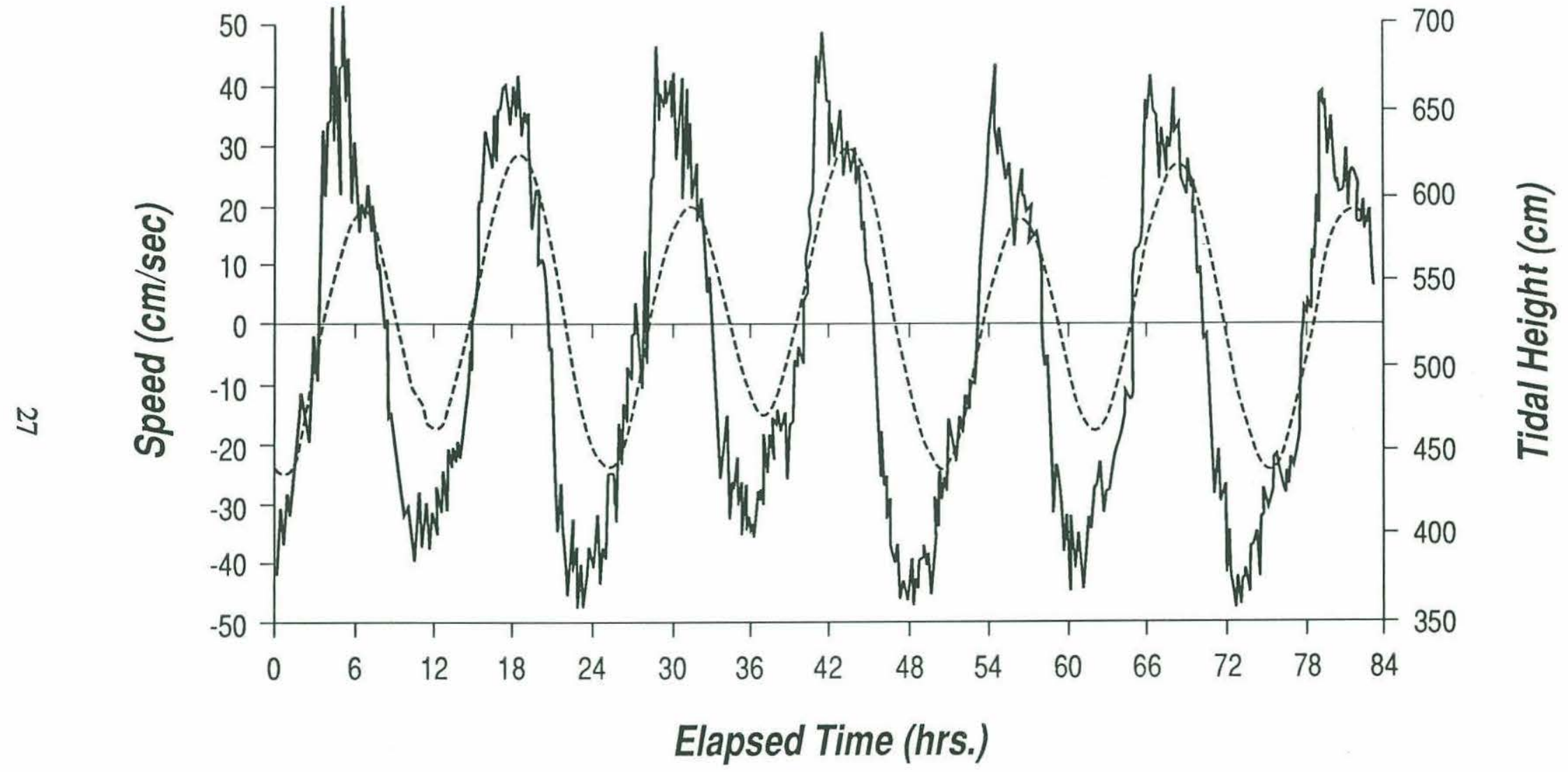

Current Speed

Tidal Height

Figure 15. Tidal currents and tidal elevations at South Channel for a three-and-a-half-day period in April, 1988. Flood currents are positive, ebb negative. 


\section{West Channel}

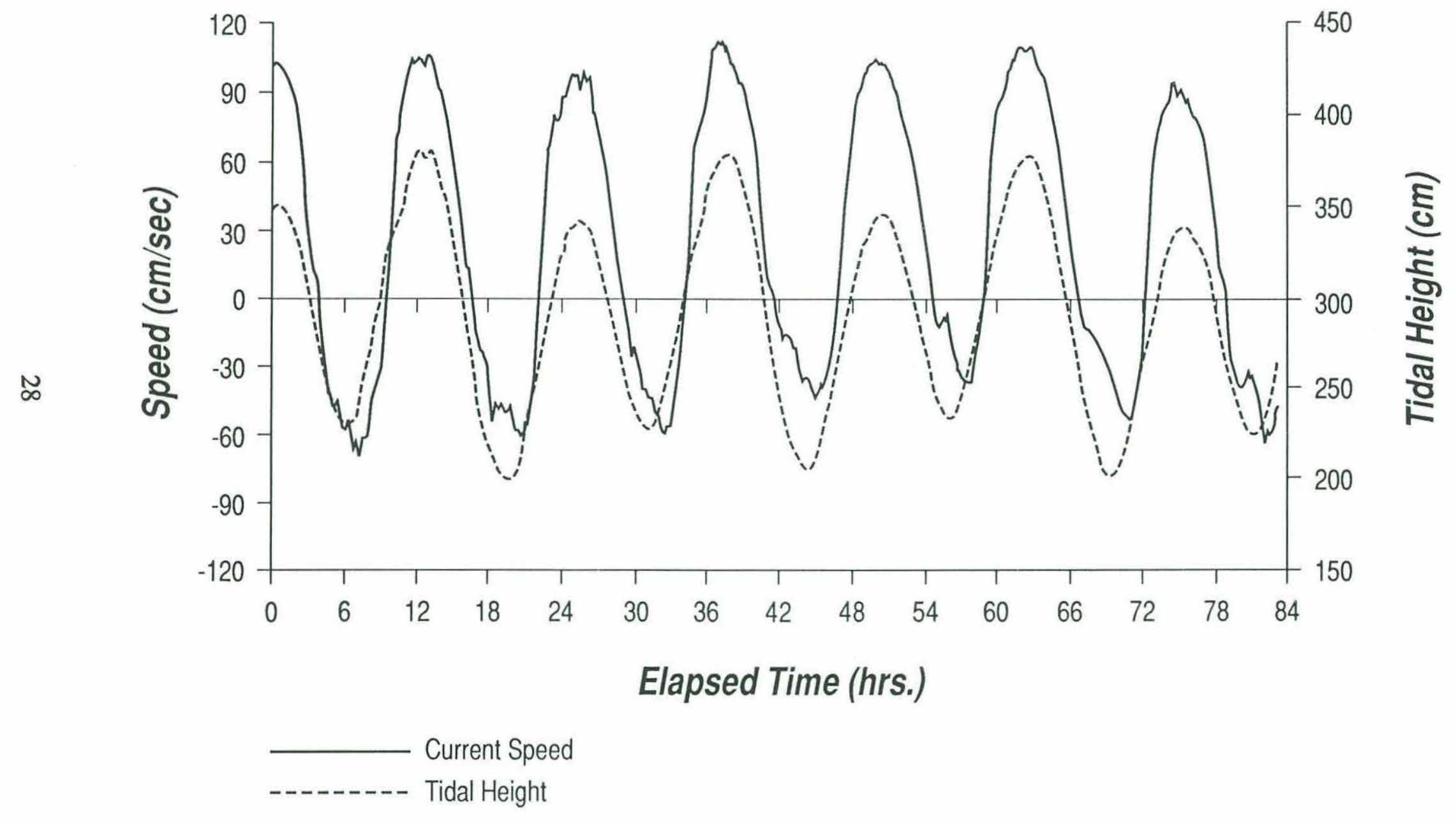

Figure 16. Tidal currents and tidal elevations at West Channel for a three-and-a-half-day period in May, 1988. Flood currents are positive, ebb negative. 
slightly. The channel is dominated by tidal currents flowing from Chatham Harbor into Nantucket Sound as indicated by the dominant positive speeds (Figure 16). The reduction in strength of currents flowing into Chatham Harbor from Nantucket Sound (negative values) reflect lower tidal ranges in Nantucket Sound, and increased friction at low water. Generally speaking, the tidal characteristics at West Channel are strikingly different from those at the other three locations.

\section{DISCUSSION}

In reviewing the results of these studies, it seems appropriate to attempt some general statements concerning the nature of the geological processes at work. The study results are consistent with the often-stated hypothesis that the tidal inlet through Nauset Beach initiated on 2 January, 1987, represents the beginning of a new cycle in the history of the Nauset-Monomoy barrier beach system. The significance of this for the purposes of resource management is that the likely general pattern of future changes (of the order of decades) is fairly clear. As part of this pattern South Beach will retreat at its northern end and eventually break into smaller segments, much of its sediment being added to the lagoon lying to the west and eventually to the inner shore and the Monomoy system, resulting in the rejoining of Monomoy to Morris Island. New Inlet will migrate southward and, eventually, so will North Beach. In the meantime, over the next two or three decades, there will be extreme shoreline changes, both erosional and depositional, along the inner shoreline of Chatham Harbor.

Given the unpredictable nature of many of the elements involved in this complex process, it is not possible to predict accurately the details of the short-term changes that lie ahead. Nevertheless, since resource owners, users and managers require as much detail concerning the future as possible, we venture to make the following tentative projections for the near future.

Tides: It is likely that for practical purposes, the increase in upper Chatham Harbor and Pleasant Bay tidal range that accompanied the formation of New Inlet is now complete. The present one-foot increase over the 1968 range is not likely to be significantly exceeded, and in fact the increasing tidal distortion indicated by the growth of the M4 overtide points to increasing tidal friction which, in turn, may lead to somewhat decreased tidal ranges. Only if a new breach were to form farther north of the existing new inlet would tidal range be expected to increase again. Significant variations in tidal height on a seasonal time frame will still occur, worsening erosion at certain times of the year.

Wave action: Vigorous wave action will continue to assault the inner shore of Chatham Harbor when tide levels and offshore waves are high. Significant coastal erosion will continue in the vicinity of the close approach of the channel bend to the inner shore. Sediment transport southward from that region will continue, as will deposition along the shore of lower Chatham Harbor. The locus of maximum erosion will shift with the position of the inlet. We expect the 
inlet to oscillate both north and south for short distances during the next couple of decades, until its inexorable southerly advance becomes stabilized.

South Beach: South Beach will continue to retreat at its northern end at a rate of about 1,000 feet per year or a little more. The cycles of spit growth into the harbor, followed by detachment and overwash of the terminal lobe, will continue and will transport significant volumes of South Beach sediment into the lower harbor. The south end of South Beach will continue to grow southward at a rate comparable to the retreat of its north end, until segmentation of South Beach occurs.

Inlet channel and shoals: The throat of the inlet channel will continue to migrate southward at a rate of somewhat more than 500 feet per year. Superimposed on this southward movement may be minor movements to the north. Inner channels in upper Chatham Harbor will become better defined, although sedimentation will continue to be a problem. Shoals will continue to develop, particularly the ebb-tide delta which will extend southward as the channel migrates in that direction.

North Beach: North Beach will continue both retreat of its vegetated dunes and cyclical spit growth and detachment. The present rate of dune retreat, somewhat less than 1,000 feet per year, will decrease through time. Spit detachment may prove to be an annual event occurring in late summer or early fall. Eventually, as the ebb-tidal delta shifts southward, net southward growth of North Beach will occur. While the timing of this can not yet be determined, there is no evidence that it will be within less than one or two decades.

\section{PROPOSED FUTURE WORK}

Additional studies will be necessary to provide Town and State environmental planners with the information required to formulate adequate management decisions relevant to this rapidly changing coastal area for the next few decades. Choosing the proper response to the many problems that lie ahead - such as the optimum location for dredged channels, the most suitable disposal areas for dredged material, and the best strategies for dealing with specific erosion or shoaling problems - will require a detailed understanding of the then-existing environmental conditions and processes, as well as the best available projections of future conditions.

Two types of studies will be required: monitoring and modeling. A basic monitoring program would provide 1) continued tide measurements at Chatham Fish Pier and Meeting House Pond, 2) continued aerial photography and land-based observations of outer beach changes, and 3) annual bathymetric surveys of the ebb-tidal delta, inlet channel throat and flood-tide shoals. An adequate modeling program would consist of 1) computer modeling of wave propagation through New Inlet and inner shoreline erosion, 2) analytical modeling of the stability of the three tidal inlets (New, South and West inlets), 3) computer modeling of the stability and fate of the three tidal 
inlets, and 4) modeling of the conditions for barrier breaching and new inlet formation. Work is presently underway on all four of these modeling studies at Woods Hole, but further support will be required to bring them to the state of completion required for practical applications.

\section{ACKNOWLEDGEMENTS}

This study was funded by the Commonwealth of Massachusetts, Department of Environmental Management, Division of Waterways, and in part by the Town of Chatham, through funds raised at Town Meeting. Additional assistance in the form of funds, equipment, data or use of facilities was provided by the Woods Hole Sea Grant Program, the U.S. Army Corps of Engineers (New England Division and Coastal Engineering Research Center), the Massachusetts Office of Coastal Zone Management, the Town of Orleans, the Friends of Pleasant Bay, the National Park Service and the U.S. Coast Guard. Among the many Chatham officials who provided special assistance are Andy Young of the Board of Selectmen; Doug Wells, chairman of the Conservation Commission; Dick Miller, chairman of the Waterways Committee; Peter Ford, Harbormaster; and Richard Batchelder, president of Friends of Chatham Waterways. Helpful federal and state officials were U.S. Representative Gerry Studds and Mark Forest of his Hyannis office, State Senator Paul Doane, State Representatives Howard Cahoon and Henri Rauschenbach, James Gutensohn, Commissioner of the Department of Environmental Management, Jack Hannon, former director of the Division of Waterways, Gene Cavanaugh, present director of the Division of Waterways, and Jeff Benoit of the Massachusetts Office of Coastal Zone Management.

Many volunteers provided valuable assistance, in particular, Richard Hiscock, Dick Miller, and Mary O'Riley of Chatham; Peter Mottur, Alexander Gryska and Christopher Edgar of Sea Education Association, and Jack Gentile of the U.S. Environmental Protection Agency. Finally, and with deepest appreciation, we recognize the hard work and good spirits of our colleagues at the Woods Hole Oceanographic Institution. 


\section{REFERENCES}

Army Corps of Engineers, 1968. Survey Report: Pleasant Bay, Chatham, Orleans, Harwich, Massachusetts. Department of the Army, New England Division, Corps of Engineers, Waltham, Massachusetts, $61 \mathrm{pp}$. + appendices.

Aubrey, D.G., 1986. A study of bluff erosion at Morris Island, Chatham, MA. A report submitted to local residents, Aubrey Consulting, Inc., Falmouth, MA, 55 pp. + appendices.

Aubrey, D.G. and P.E. Speer, 1984. Updrift migration of tidal inlets. Journal of Geology, v. 92, p. 531-545.

Aubrey, D.G. and P.E. Speer, 1985. A study of non-linear tidal propagation in shallow inlet/estuarine systems. Part I: Observations. Estuarine, Coastal and Shelf Science, v. 21, p. $185-205$.

Giese, G.S., 1978. The barrier beaches of Chatham, Massachusetts. Provincetown Center for Coastal Studies Report, April 1978, and Cape Cod Chronicle, June 1, 1978, Special Supplement, 7 pp.

Giese, G.S., 1988. Cyclical Behavior of the Tidal Inlet at Nauset Beach, Chatham, Massachusetts. In: D.G. Aubrey and L. Weishar (eds.), Hydrodynamics and Sediment Dynamics of Tidal Inlets, Springer-Verlag, NY, p. 269-283.

Goldsmith, V., 1972. Coastal processes of a barrier island complex and adjacent ocean floor: Monomoy Island - Nauset Spit, Cape Cod, Massachusetts. Unpublished doctoral dissertation, Univ. Massachusetts, 469 pp.

Leatherman, S.P. and Zaremba, R.E., 1986. Dynamics of a northern barrier beach: Nauset Spit, Cape Cod, Massachusetts. Geological Society of American Bulletin, 97:116-124.

McClennen, C.E., 1979. Nauset Spit: Model of Cyclical Breaching and Spit Regeneration During Coastal Retreat. In: Leatherman, S.P. (ed.), Environmental Geological Guide to Cape Cod National Seashore, S.E.P.M., Eastern Section Field Trip Guide Book, Boulder, CO, p. 109-118.

Mitchell, H., 1874. Report to Prof. Benjamin Pierce, Superintendent United States Coast Survey, concerning Nauset Beach and the peninsula of Monomoy. Report of the superintendent of the United states Coast Survey for 1871, Appendix No. 9, p. 134-143.

Oldale, R.N., Friedman, J.D. and Williams, R.S., Jr., 1971. Changes in coastal morphology of Monomoy Island, Cape Cod, Massachusetts. U.S. Geological Survey Prof. Paper 750-B, p. B101-B107.

Weidman, C. and Eberts, J., 1988. The Chatham inlet study. Final report to the Research Foundation, SUNY-Oneonta, Oneonta, NY. 


\section{DOCUMENT LIBRARY}

May 5, 1989

Distribution List for Technical Report Exchange

Attn: Stella Sanchez-Wade

Documents Section

Scripps Institution of Oceanography

Library, Mail Code C-075C

La Jolla, CA 92093

Hancock Library of Biology \& Oceanography

Alan Hancock Laboratory

University of Southern California

University Park

Los Angeles, CA 90089-0371

Gifts \& Exchanges

Library

Bedford Institute of Oceanography

P.O. Box 1006

Dartmouth, NS, B2Y 4A2, CANADA

Office of the International

Ice Patrol

c/o Coast Guard R \& D Center

Avery Point

Groton, CT 06340

\section{Library \\ Physical Oceanographic Laboratory \\ Nova University \\ 8000 N. Ocean Drive}

Dania, FL 33304

NOAA/NESDIS Miami Library Center 4301 Rickenbacker Causeway

Miami, FL 33149

Library

Skidaway Institute of Oceanography

P.O. Box 13687

Savannah, GA 31416

Institute of Geophysics

University of Hawaii

Library Room 252

2525 Correa Road

Honolulu, HI 96822

Library

Chesapeake Bay Institute

4800 Atwell Road

Shady Side, MD 20876

MIT Libraries

Serial Journal Room 14E-210

Cambridge, MA 02139
Director, Ralph M. Parsons Laboratory

Room 48-311

MIT

Cambridge, MA 02139

Marine Resources Information Center

Building E38-320

MIT

Cambridge, MA 02139

Library

Lamont-Doherty Geological Observatory

Colombia University

Palisades, NY 10964

Library

Serials Department

Oregon State University

Corvallis, OR 97331

Pell Marine Science Library

University of Rhode Island

Narragansett Bay Campus

Narragansett, RI 02882

Working Collection

Texas A\&M University

Dept. of Oceanography

College Station, TX 77843

Library

Virginia Institute of Marine Science

Gloucester Point, VA 23062

Fisheries-Oceanography Library

151 Oceanography Teaching Bldg.

University of Washington

Seattle, WA 98195

Library

R.S.M.A.S.

University of Miami

4600 Rickenbacker Causeway

Miami, FL 33149

Maury Oceanographic Library

Naval Oceanographic Office

Bay St. Louis

NSTL, MS 39522-5001

Marine Sciences Collection

Mayaguez Campus Library

University of Puerto Rico

Mayagues, Puerto Rico 00708 


\begin{tabular}{|l|l|l|}
\hline \multicolumn{1}{|c|}{$\begin{array}{c}\text { REPORT DOCUMENTATION } \\
\text { PAGE }\end{array}$} & $\begin{array}{c}\text { 1. REPORT NO. } \\
\text { WHOI-89-19 (CRC-89-4) }\end{array}$ & 3. Recipient's Accession No. \\
\hline $\begin{array}{l}\text { 4. Title and Subtitle } \\
\text { Development, Characteristics, and Effects of the New Chatham Harbor Inlet }\end{array}$ & $\begin{array}{r}\text { 5. Report Date } \\
\text { June } 1989\end{array}$ & $\mathbf{6 .}$ \\
\hline $\begin{array}{l}\text { 7. Author(s) } \\
\text { Graham S. Giese, David G. Aubrey and James T. Liu }\end{array}$ & $\begin{array}{c}\text { 8. Performing Organization Rept. No. } \\
\text { WHOI-89-19 }\end{array}$ \\
\hline $\begin{array}{l}\text { 9. Performing Organization Name and Address } \\
\text { The Woods Hole Oceanographic Institution }\end{array}$ & $\begin{array}{c}\text { 10. Project/TaskWork Unit No. } \\
\text { Woods Hole, Massachusetts 02543 }\end{array}$ & $\begin{array}{l}\text { 11. Contract(C) or Grant(G) No. } \\
\text { (C) }\end{array}$ \\
(G) \\
\hline $\begin{array}{l}\text { 12. Sponsoring Organization Name and Address } \\
\text { Commonwealth of Massachusetts, Department of Environmental Management, Division of } \\
\text { Waterways; the Town of Chatham; Woods Hole Sea Grant Program; Massachusetts Office of } \\
\text { Coastal Zone Management; U.S. Army Corps of Engineers (New England Division and Coastal } \\
\text { Engineering Research Center); Town of Orleans; and Friends of Pleasant Bay. }\end{array}$ & $\begin{array}{l}\text { 13. Type of Report \& Period Covered } \\
\text { Technical Report }\end{array}$ \\
\hline
\end{tabular}

15. Supplementary Notes

This report should be cited as: Woods Hole Oceanog. Inst. Tech. Rept., WHOI-89-19. CRC-89-4.

16. Abstract (Limit: 200 words)

A new tidal inlet into Chatham Harbor, Massachsuetts, has developed from a breach in the barrier beach, Nauset Beach, that forms the outer shoreline of southeastern Cape Cod. Increased tidal range and wave energy resulting from the new inlet produced acute coastal erosion and channel shoaling within Chatham Harbor, with significant impacts on the fishing and boating industries, and on private and public property and interest. Study results are consistent with the hypothesis that the Nauset-Monomoy barrier beach system undergoes a long-term cycle of geomorphological change, and that a new cycle was initiated with the formation of this new inlet. Based on this new understanding, future changes in the system can be foreseen and provided to coastal resource managers.

17. Document Analysis a. Descriptors

1. Tidal Inlet

2. Barrier Beach

3. Coastal Erosion

4. Sediment Transport

b. Identifiers/Open-Ended Terms

c. COSATI Field/Group

18. Availability Statement

Approved for publication; distribution unlimited.

19. Security Class (This Report)

UNCLASSIFIED

20. Security Class (This Page)
21. No. of Pages 33

22. Price 